\title{
Szczepienia seniorów - profilaktyka chorób zakaźnych na przykładzie szczepienia przeciw grypie
}

\section{Seniors vaccinations- prevention of contagious diseases on the ex ample of influenza vaccination}

\author{
MAGDALENA ZAWIDZKA ${ }^{1}$, ELŻBIETA NAZAR ${ }^{1}$, MARTA KAMIŃSKA $^{1}$, \\ JOANNA PRZYBYLSKA 2,3 \\ 1Studenckie Koło Naukowe Nauk o Zdrowiu, Instytut Nauk o Zdrowiu PWSZ \\ we Włocławku, opiekun Koła: dr Beata Haor \\ 2 Instytut Nauk o Zdrowiu, PWSZ we Włocławku \\ ${ }^{3}$ Miejski Zespół Opieki Zdrowotnej Sp z o.o. we Włocławku
}

DOI: http://dx.doi.org/10.21784/IwP.2018.018

ISSN: 2451-1846

\section{Streszczenie:}

Wstęp. Grypa to choroba zakaźna układu oddechowego pojawiająca się najczęściej, niezależnie od wieku. Osobom starszym oprócz szczepienia przeciw grypie zaleca się szczepienia przeciw zapaleniu płuc, wirusowemu zapaleniu wątroby (WZW) typu B, krztuścowi, błonicy oraz tężcowi. Celem niniejszej pracy jest przedstawienie istoty szczepienia przeciwko grypie oraz udziału seniorów w „Programie profilaktyki chorób zakaźnych w zakresie szczepień ochronnych przeciw grypie dla osób powyżej 65 roku życia", na przykładzie miast Włocławek, Lublin oraz Wrocław.

Przegląd. Choroby zakaźne występujące u osób w podeszłym wieku często charakteryzują się ciężkim przebiegiem i zwiększonym ryzykiem powikłań. Pomimo szeroko ukierunkowanej prewencji infekcji wśród osób starszych, najbardziej efektywnym oraz najskuteczniejszym sposobem 
zapobiegania grypie, a także jej powikłaniom, są szczepienia ochronne. Stopień wyszczepienia pacjentów powyżej 65 roku życia jest niski. Stosowanie szczepień ochronnych ma korzystny wpływ nie tylko na zdrowie pacjentów, ale także na obniżenie kosztów leczenia związanych z wystąpieniem ewentualnych powikłań pogrypowych oraz długotrwałej hospitalizacji. Systematyczne powtarzanie szczepień przeciwko grypie pozwala nie tylko chronić przed infekcją oraz powikłaniami, ale także pobudza układ obronny organizmu do skutecznego działania.

Wnioski. Pomimo zaleceń specjalistów, popularność szczepień wśród osób po 65 roku życia jest bardzo niska. Do najczęstszych przyczyn związanych $\mathrm{z}$ rezygnacją ze szczepień u seniorów należą: lęk przed powikłaniami związanymi ze szczepieniem oraz brak wiary $\mathrm{w}$ jego skuteczność. Z tego powodu niezwykle ważne jest efektywne promowanie szczepień przeciw grypie wśród osób w podeszłym wieku.

Słowa kluczowe: grypa, wiek podeszły, szczepienia

\begin{abstract}
:
Introduction. Influenza has been known as the most common contagious disease attacking the respiratory system of patients at any age. In addition to influenza vaccination, older people are also advised to vaccinate against pneumonia, hepatitis (Hepatitis B), pertussis, diphtheria and tetanus. The aim of this work is to present the importance of influenza vaccination and senior participation in the "Program for the prevention of contagious diseases with respect to the use of influenza vaccination for people over 65", on the example of Włocławek, Lublin and Wrocław.
\end{abstract}

Overview. Contagious diseases in older people are often characterized by a severe course and an increased risk of complications. Despite the wide-scale infection prevention among the older people, protective vaccinations are the most effective way to prevent influenza, as well as its complications. The number of vaccinated patients over 65 is low. The use of protective vaccinations has a beneficial effect not only on the health of patients, but also on the reduction of treatment costs associated with the occurrence of possible post-influenza complications and long-term hospitalization. Systematic influenza vaccinations are liekely to protect patients from infection and complications, but also stimulate the body's immune system to function properly. 
Conclusions. Despite the recommendations of health professionals , the popularity of vaccinations among people over 65 is very low. The most common reasons associated with resignation from vaccinations among seniors include: fear of complications associated with vaccination and lack of faith in its effectiveness. For this reason, it is extremely important to effectively promote influenza vaccinations among the elderly.

Keywords: influenza, old age, vaccinations

\section{Wstęp}

Współczesne społeczeństwa cechują się coraz większą liczbą seniorów. Aktualnie w Polsce grupę ponad 14\% populacji stanowią osoby będące powyżej 65 roku życia [1]. Starość jest jedną z faz życia człowieka, zjawiskiem społecznym oraz biologicznym, które wpisuje się w proces starzenia demograficznego [1].

Choroby zakaźne stanowią dla seniorów duże zagrożenie. Powikłania wynikające z zakażeń mogą doprowadzić do poważnych konsekwencji zdrowotnych a nawet zgonu seniora [2]. Infekcje układu oddechowego na tle wirusowym manifestują się szeregiem objawów klinicznych. Według raportów WHO wynika, iż na świecie co roku na grypę lub grypopodobne choroby umiera około $5-25 \%$ społeczeństwa [1]. Dlatego ważnym elementem ich profilaktyki są szczepienia przeciw chorobom zakaźnym.

Na podstawie zaleceń opublikowanych w 2010 roku przez grupę ekspertów European Union Geriatric Medicine Society i International Asociation of Gerontology and Geriatrics European Region osoby starsze powinny być szczepione przeciw krztuścowi, tężcowi, błonicy, pneumokokom, półpaścowi oraz przeciw grypie [1- ]. W ramach corocznie ogłaszanego programu szczepień przez Główny Inspektorat Sanitarny rekomenduje się, by osoby, które skończyły 60 rok życia zaszczepiły się przeciwko grypie raz w roku; raz na 10 lat na tężec, błonice i krztusiec; ospie wietrznej oraz WZW typu Bw trzech dawkach [1,4]. Szczepienia przeciwko grypie 
rekomendowane są Polsce od roku 1994. Systematyczne szczepienia podczas sezonu zachorowań zwiększają szanse, na uniknięcie poważnych komplikacji wynikających $\mathrm{z}$ zachorowania na grypę $[1,3,4]$.

W roku 2013 został opublikowany raport pt. "Stosunek do szczepień przeciwko grypie" opracowany przez Centrum Badania Opinii Społecznej. Wykazał, iż w każdym roku odsetek osób poddających się szczepieniom maleje. W sezonie jesienno-zimowym korzystało ze szczepień zaledwie około $4 \%$ populacji, natomiast liczba chorych wzrosła ponad trzykrotnie a hospitalizowanych z powodu grypy aż czterokrotnie. Wśród głównych przyczyn rezygnowania ze szczepień respondenci wskazywali na m.in. przekonanie, że nie przyniosą one oczekiwanego efektu oraz podkreślali strach przed niepożądanym odczynem poszczepiennym (NOP) [1,2,5].

Celem niniejszej pracy jest przedstawienie jak ważnym elementem dla zdrowia jest szczepienie przeciwko grypie oraz udziału seniorów w „Programie profilaktyki chorób zakaźnych w zakresie szczepień ochronnych przeciw grypie dla osób powyżej 65 roku życia”, na przykładzie miast: Włocławek, Lublin oraz Wrocław.

\section{Przegląd literatury}

Grypa należy do ostrych infekcji wirusowych układu oddechowego. Wśród ludzi najczęściej przenoszona jest drogą kropelkową oraz kontaktową [6,7,11]. Okres, w którym trwa inkubacja choroby przypada na 1-4 dni, najczęściej trwa to średnio: 1-2 dni. W zależności od wieku pacjenta i stanu odporności czas zakaźności choroby jest różny. U dzieci wydalanie wirusa przypada na 6 do 10 dnia od pojawienia się objawów chorobowych. Natomiast u dorosłego ma to miejsce na jeden dzień przed pojawieniem się pierwszych objawów i 5-7 dni po ich wystapieniu $[9,12]$. 
Do głównych objawów klinicznych grypy sezonowej należą m.in. kaszel, katar, ból gardła, gorączkę, dreszcze, bóle stawowomięśniowe, bóle głowy, bóle w klatce piersiowej, złe samopoczucie, nudności i wymioty. Objawy te mijają w ciągu 3-5 dni, jednakże kaszel i ogólne złe samopoczucie mogą się znacznie przedłużyć, niekiedy nawet ponad 2 tygodnie [9-12].

Grypę wywołują przede wszystkim 2 typy wirusa: A i B. Typ A występuje u ludzi i zwierząt (m.in. świń, koni, fok oraz ptaków). Jest on uznawany za najgroźniejszy ze względu na największą skłonność do mutacji oraz możliwość łamania ograniczeń międzygatunkowych. Mutacje, jakie zachodzą podczas replikacji powodują powstawanie nowych wariantów wirusa. W grupie wirusów typu A wyróżniono zostało kilka podtypów, w zależności od budowy antygenów powierzchniowych hemaglutyniny (antygen H) i neuraminidazy (antygen N). Typ B wirusa dotyczy wyłącznie u ludzi. Charakteryzuje go umiarkowany przebieg choroby. Nie wykazuje on zdolności do pokonywania barier międzygatunkowych [6-8,12].

Metody biologii molekularnej pozwalają na rozpoznanie zakażenia wirusami grypy już po 3 godzinach. Daje to możliwość leczenia przyczynowego. Według Zakładu Badania Wirusów Grypy, Krajowego Ośrodka ds. Grypy w Narodowym Instytucie Zdrowia Publicznego, aby uniknąć zachorowania na grypę, należy się szczepić w każdym sezonie epidemicznym. Główny Inspektorat Sanitarny zaleca szczepienia osobom starszym. Co roku ogłasza Program Szczepień Ochronnych, np. Program Szczepień Ochronnych na rok 2018 został ogłoszony w Dzienniku Urzędowym Ministra Zdrowia z dnia 31 października 2017 roku. Szczepienia przeciwko grypie sklasyfikowane są jako szczepienia zalecane [13]. W 2017 roku w ramach programu polityki zdrowotnej, m.in. Włocławek, Wrocław i Lublin postanowiły sfinansować szczepienia dla seniorów.

Włocławek Uchwałą Rady Miasta z dnia 28 sierpnia 2017 roku przyjął „Program szczepień ochronnych przeciwko grypie dla osób powyżej 65 roku życia, zamieszkałych na terenie miasta Włocławek" 
obowiązujący w latach 2017-2019. Jako cel główny Program zakłada poprawę stanu zdrowia mieszkańców Włocławka poprzez wykonane szczepienia przeciwko grypie oraz prowadzone działania edukacyjne. Efektem podjętych działań ma być zwiększenie liczby szczepiących się osób objętych programem oraz osób z innych grup wiekowych, zmniejszenie zachorowań na grypę, liczby wizyt ambulatoryjnych oraz hospitalizacji z powodu grypy i jej powikłań. Efekty realizacji programu będą oceniane na podstawie danych gromadzonych przez Powiatową Stację Sanitarno-Epidemiologiczną oraz Narodowy Instytut Zdrowia Publicznego - Państwowy Zakład Higieny. Program zakłada, że rocznie skorzysta ze szczepień 5 do 10\% z grupy 20785 osób (stan na dzień 01.06.2017) tj. od 1040 do 2078 seniorów. Kampania informacyjno-edukacyjna ma być prowadzona na stronie internetowej Urzędu Miasta (www.wloclawek.pl), lokalnych mediach, tablicach ogłoszeniowych, a także $w$ przychodniach i gabinetach podstawowej opieki zdrowotnej. Skorzystać z Programu będą mogły osoby zamieszkujące we Włocławku, mające 65 lat i więcej, u których brak jest przeciwwskazań lekarskich do zaszczepienia oraz które zgłosiły się przed wyczerpaniem budżetu programu na dany rok. Szacowany koszt zaszczepienia w 2017r. 1 osoby to $36 \mathrm{zł}$. W tej wartości ujęta została wartość szczepionki, badania lekarskiego, podania szczepionki oraz koszt obsługi administracyjno-technicznej podmiotu udzielającego świadczenia zdrowotnego. Całkowity budżet programu to na rok 2017 to $50.000 \mathrm{zl}$, w tym wydatki związane z przeprowadzeniem szczepień 46.800 zł i ok. 3.000 zł koszty akcji promocyjnej. Planowany całkowity koszt Programu w latach 20172019 wyniesie 220.000 zł. Do monitorowania i ewaluacji programu posłużą comiesięczne raporty na temat zgłaszalności do programu, ankiety wypełniane przez uczestników programu oraz dane na temat m.in. liczby osób, które zgłosiły się do programu, zostały zaszczepione, liczby niepożądanych odczynów poszczepiennych oraz statystyk zapadalności na grypę (PSSE, NIZP-PZH). Rada Miasta zakłada możliwość kontynuacji programu w latach następnych [9]. 
Urząd Miejski Wrocławia Wydział Zdrowia i Spraw Społecznych przyjął na lata 2017-2021 „Program szczepień ochronnych przeciw grypie dla mieszkańców Wrocławia w wieku 65+". Wrocław liczy sobie prawie 636 tys. mieszkańców, w tym ok. 117 tys. osób powyżej 65 roku życia. Program zakłada objęcie szczepieniami ochronnymi corocznie około 5 tys. osób, szczególnie z grup podwyższonego i wysokiego ryzyka czyli tylko 4\% seniorów. W związku $\mathrm{z}$ ograniczonymi finansami i możliwościami organizacyjnymi, twórcy programu kładą nacisk na działania edukacyjne wśród seniorów. Mają one być prowadzone w mediach lokalnych $\mathrm{w}$ formie komunikatów (radio, telewizja, prasa, strona internetowa UM Wrocław) oraz w formie plakatów zamieszczonych w placówkach medycznych (m.in. POZ), Klubach Seniora, Uniwersytetach III Wieku i innych miejscach użyteczności publicznej, a także podczas wrześniowych Dni Promocji Zdrowia. Oczekiwane efekty i sposób ich oceniania, metody oceny i ewaluacji Programu są takie same jak we Włocławku. Również szacunkowa cena zaszczepienia 1 osoby to ok. 36 zł. Całkowity koszt realizacji 5letniego Programu to 900.000 zł. Są to środki w 100\% z budżetu Miasta Wrocławia. Nadmienić należy, iż Wrocław za wieloletnie popularyzowanie wśród mieszkańców miasta profilaktyki grypy, otrzymał w 2015 roku tytuł Eksperta Ogólnopolskiego Programu Zwalczania Grypy [10].

Dnia 27 kwietnia 2017 roku Uchwałą Rady Miasta Lublin został przyjęty „Program profilaktyczny chorób zakaźnych w zakresie szczepień ochronnych przeciw grypie dla osób powyżej 65 roku życia" na lata 2016-2020. Cele Programu, efekty, mierniki, ewaluacja i monitorowanie są zbieżne $\mathrm{z}$ Programami miast Włocławek i Wrocław. Władze miasta Lublin do realizacji programu oprócz środków z budżetu miasta, chcą pozyskać środki z funduszy europejskich. Program ma objąć mieszkańców Lublina powyżej 65 roku życia. Liczba seniorów w 2014 roku to 57.850 osób co stanowiło 16,9\% wszystkich mieszkańców miasta. Szczepieniom 
corocznie ma się poddać około 11.000 osób, co stanowić będzie około 18\% populacji mieszkańców powyżej 65 roku życia. Budżet Programu przez 5 lat swego istnienia ma się zamknąć w kwocie 1.766 .930 zł. Koszt szczepienia 1 osoby czyli koszt szczepionki, badania lekarskiego kwalifikującego do zaszczepienia, koszty utylizacji odpadów, akcji informacyjnej, edukacji pacjenta został oszacowany na 30 zł. Wycena została wykonana na podstawie dotychczasowych kosztów realizacji programu. W akcję propagującą Program profilaktyczny chorób zakaźnych, oprócz zaangażowania lokalnych mediów oraz placówek medycznych, ma się włączyć Prezydent Miasta Lublin podczas konferencji na temat szczepień [8].

\section{Wnioski}

Przedstawione wyżej założenia: „Programu szczepień ochronnych przeciwko grypie dla osób powyżej 65 roku życia, zamieszkałych na terenie miasta Włocławek" obowiązującego na lata 2017-2019, „Programu szczepień ochronnych przeciw grypie dla mieszkańców Wrocławia w wieku 65+" na lata 2017-2021 oraz "Programu profilaktycznego chorób zakaźnych w zakresie szczepień ochronnych przeciw grypie dla osób powyżej 65 roku życia" w Lublinie na lata 2016-2020 stanowią pozytywny przykład odpowiedzi ze strony władz lokalnych na ogłaszany co roku przez Ministra Zdrowia „Program Szczepień Ochronnych”.

Szczepienia przeciwko grypie dla osób w wieku 65+ sklasyfikowane są jako zalecane, czyli nierefundowane przez NFZ. Władze wspomnianych wcześniej miast postanowiły sfinansować szczepienia ze swojego budżetu dla pewnego odsetka swoich mieszkańców: Włocławek dla 5-10\%, Wrocław dla 4\%, Lublin 18\% rocznie. Głównym celem programów profilaktycznych realizowanych w tych trzech miast, jest poprawa stanu zdrowia mieszkańców poprzez wykonane szczepienia przeciwko grypie oraz dzięki prowadzonym działaniom edukacyjnym. W działania promocyjnoedukacyjnej zostaną zaangażowane lokalne media oraz placówki 
medyczne. Efektem programów ma być zwiększenie liczby zaszczepionych osób, a tym samym zmniejszenie zachorowalności na grypę, co wymiernie przełoży się na redukcję kosztów wizyt ambulatoryjnych i hospitalizacji. Efekty realizacji Programów będą oceniane na podstawie danych gromadzonych przez Powiatowe Stacje Sanitarno-Epidemiologiczne właściwe dla danego terenu oraz Narodowy Instytut Zdrowia Publicznego - Państwowy Zakład Higieny. Do monitorowania i ewaluacji programów posłużą comiesięczne raporty na temat zgłaszalności osób do programu, ankiety wypełniane przez jego uczestników oraz dane z PSSE i NIZP-PZH. Zaletą Programów jest zagwarantowanie jego uczestnikom bezpłatnych szczepionek, które mają być finansowane ze środków budżetów miasta Włocławek i Wrocław. Natomiast Lublin zamierza dodatkowo pozyskać dofinansowanie z funduszy europejskich. Władze wszystkich w/w miast zamierzają kontynuować Programy szczepień ochronnych dla seniorów w kolejnych latach, co z pewnością istotnie przyczyni się do poprawy stanu zdrowia populacji seniorów.

\section{Bibliografia/Bibliography:}

1. Szczerbińska K., Barańska I., Brzyski P., Ocetkiewicz T., Wiedza, przekonania i zachowania osób starszych wobec szczepień ochronnych zalecanych $\mathrm{w}$ starszym wieku. GERONTOLOGIA POLSKA, 2014, 2, s.51-61.

2. Woźniak-Kosek A. , Kosek J. , Chrząstek L., Empiryczna analiza zachowań i wiedzy dotyczącej szczepień przeciwko grypie wśród słuchaczy Częstochowskiego Uniwersytetu III Wieku na podstawie badań ankietowych. GERIATRIA, 2014, 8, s. 221-231.

3. https://gis.gov.pl/zdrowie/szczepienia-dla-osob-starszych/. 
4. http://zaszczepsiewiedza.pl/aktualnosci/szczepienia-seniorowwazna-czesto-pomijana-profilaktyka-chorob-zakaznych/.

5. https://www.cbos.pl/SPISKOM.POL/2013/K_169_13.PDF.

6. http://www.euro.who.int/en/health-topics/communicablediseases/influenza.

7. Strach M. Szczepienie przeciwko grypie u osób w podeszłym wieku. GERONTOLOGIA POLSKA, 2009, 2, s.103-105.

8. Uchwała Nr 739/XXIX/2017 Rady Miasta Lublin z dnia 27 kwietnia 2017 r. w sprawie przyjęcia programu polityki zdrowotnej „Program profilaktyczny chorób zakaźnych w zakresie szczepień ochronnych przeciw grypie dla osób powyżej 65 roku życia".

9. Uchwała Nr XXXIII/101/2017 Rady Miasta Włocławek z dnia 28 sierpnia 2017 r. w sprawie przyjęcia programu polityki zdrowotnej pn. „Program szczepień ochronnych przeciw grypie dla osób powyżej 65 roku życia, zamieszkałych na terenie miasta Włocławek" na lata 2017-2019.

10. Ogłoszenie o przetargu na stronie internetowej Urzędu Miasta Wrocław (http://bip.um.wroc.pl/przetarg/29425/programszczepien-ochronnych-przeciw-grypie-dla-mieszkancow-wroclawiaw-wieku-65, zał. nr 1, dostęp:30.08.2018).

11. https://www.gov.pl/zdrowie/grypa.

12. Brydak L.: Grypa. Pandemia grypy - mit czy realne zagrożenie? Rhythm, Warszawa 2008, s. 1-92.

13. http://www.pzh.gov.pl/grypa/. 